\title{
Grave New World? Workplace Skills For Today's College Graduates
}

Susan Eisner, Ramapo College of New Jersey, USA

\begin{abstract}
Today's college graduates face an uncertain and demanding job market in which they are likely to encounter evolving skill needs, reduced hiring, and heightened competition from experienced laid off workers and globally available labor. These realities underscore the importance expressed by educators and practitioners of identifying attributes new college graduates should have to meet the challenges and access opportunities of the $21^{\text {st }}$ century workplace. This paper identifies those core competencies through comprehensive literature review, original studies using primary data, and contextual analysis of the contemporary workplace in which the skills will be valued.
\end{abstract}

Keywords: Business Education, College Graduates, Economy, Employment, Great Recession, Human Resources, Jobs, Work Readiness, Work Skills

\section{INTRODUCTION}

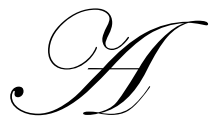

s an estimated 1.5 million U.S. undergraduates received bachelors degrees in 2009, an estimated 1.9 million U.S. workers holding bachelor degrees or higher were unemployed (Hansen, 2009b). The overall U.S. unemployment rate ${ }^{1}$ in the workforce the new graduates prepared to enter had reached $10 \%$ by year's end, doubling that rate from two years earlier when the Great Recession began. In addition to the 15.3 million U.S. people out of work by December 2009, 9.2 million were working part-time but wanted to work full-time. Another 2.5 million out of work wanted to work but were not counted as unemployed, since they had not looked for work in the past four weeks (BLS, 2010). Experts estimate that if the 661 thousand discouraged workers who dropped out of the labor force in December 2009 had continued to look for work, the U.S. unemployment rate would have reached $10.4 \%$ at that two-year recessionary marker. Concurrently, the underemployment rate, which counts part-time workers wanting to work full-time and people wanting to work but unable to find it, rose to $17.3 \%$ (Willis and Schlissermann, 2010). The highest U.S. underemployment rate recorded prior to the Great Recession was $17.1 \%$ in 1982 (Leonhardt, 2009).

As a result, new U.S. graduates appear to be facing a grave new world: A job market experiencing the longest lasting recession since the 1930s (Andrews, 2009) and the disappearance of more jobs proportional to the workforce than at any time since the end of World War II (Norris, 09). Some 7 million U.S. jobs were lost between 2007and 2009 (Economic Policy Institute, 2009). The number of those seeking U.S. work outnumbered available jobs by a record 6 to 1. During the most recent prior recession in 2001, that ratio was 2 to 1 (Goodman, 2009). Economists predict that unemployment will remain between 9\% and 10\% throughout 2010 (Ahrens, 2010) and estimate that a quarter of a million U.S. jobs must be added each month just to keep pace with the rate of population growth (Economic Policy Institute, 2009). Some analysts envision more job cutbacks in 2012-2015 when more than $\$ 700$ billion in junk-bond related corporate debt comes due (Schwartz, 2010).

Within this context, education appears to have a positive effect. The Bureau of Labor Statistics of the U.S. Department of Labor (BLS) data that reports unemployment levels by educational attainment shows those possessing bachelors degrees or higher having stronger labor force participation rates ${ }^{2}$ than any other educational

\footnotetext{
${ }^{1}$ The percentage of the labor force that is not employed (Source: http://www.bls.gov/bls/glossary.htm\#U).

2 The percentage of the total civilian noninstitutional population that is in the labor force (Source:
} http://www.bls.gov/bls/glossary.htm\#U). 
group. Some $77.4 \%$ of those with bachelors degrees or higher were in the 2009 labor force as compared to $70.6 \%$ with some college education but no bachelors degree, $62.1 \%$ with high school diplomas only, and $47.3 \%$ with less than a high school diploma. Moreover, as seen in Table 1, the unemployment rate consistently drops among these groups as their educational attainment level increases (BLS, 2009c).

Table 1: Unemployment Rate by Level of Educational Attainment

\begin{tabular}{|l|c|c|c|c|c|c|}
\hline Level of Educational Attainment & \% in 9'08 & \% in 5'09 & \% in 6'09 & \% in 7'09 & \% in 8'09 & \% in 9'09 \\
\hline No high school diploma & 9.8 & 15.5 & 15.5 & 15.4 & 15.6 & 15.0 \\
\hline High school diploma only & 6.3 & 10.0 & 9.8 & 9.4 & 9.7 & 10.8 \\
\hline Some college or associates degree & 5.1 & 7.7 & 8.0 & 7.9 & 8.2 & 8.5 \\
\hline Bachelors degree or higher & 2.6 & 4.8 & 4.7 & 4.7 & 4.7 & 4.9 \\
\hline
\end{tabular}

But the environment awaiting new college graduates is not clear cut. The U.S. unemployment rate of $2 \%$ at the start of the Great Recession for those aged 25 or over with bachelors degrees or higher (BLS, 2009a) more than doubled over its two-year period, and reached its highest rate since BLS in 1970 began tracking unemployment by educational level (Shin, 2009). By December 2009, that highest education level unemployment rate neared the 5\% that had been the national unemployment rate two years earlier (BLS, 2010). Additionally, while the widely reported BLS data reflects unemployment levels by educational attainment of those aged 25 and over, an Economic Policy Institute study reported the unemployment rate for those with bachelors degrees under the age of 27 to have reached 7\% in 2009 (Kleinfield, 2009).

The job market awaiting new college graduates reflects these complexities. The 2009 Annual Job Forecast Survey conducted by Careerbuilder found the majority of employers not planning to hire recent college graduates, and a 13\% drop from the prior year in the number planning to do such hiring (Zupek, n.d.). The National Association of Colleges and Employers (NACE) reported employer plans for hiring 2009 college graduates to be the worst in six years, with the majority planning to decrease such hiring (What College Grads Can Expect Out of the Job Market, 2009). A survey conducted by NACE of college students in the class of 2009 found only $19.7 \%$ of those who had applied for post-graduation jobs to have been hired, as compared with $26 \%$ with jobs upon graduating in 2008 and 51\% with jobs upon graduating in 2007 (Hansen, 2009a).

A 2009 Business Week article described new college graduates as facing the worst job market in decades. It characterized that market as having reduced hiring and leveled salaries, and the economy as moving toward a jobless recovery (Glover, 2009). Recruiters described new graduates as facing increased competition from laid off job seekers who have stronger experiential qualifications in addition to bachelors degrees, and employers thus able to hire more selectively (Shin, 2009). Employers appear to have favored those more experienced hires over lowercost new graduates, perhaps in anticipation of future economic disruption or retirements of more advanced workers when the economy recovers (Owens, 2009; Collegiate Employment Research Institute, n.d.). The result? In 2009 the highest rate of new college graduates in some 18 years were working in jobs that did not require college degrees. Taking what work could be found, half of college graduates under the age of 25 were in such jobs (Rampell, 2009).

At the same time, there are upside indicators. Careerbuilder's survey found $43 \%$ of employers did plan to hire 2009 new college grads (Zupek, n.d.). CollegeGrad.com reported that although 2009 entry level hiring was down $1.5 \%$ from the prior year, it was 11.4\% higher than in 2007 (CollegeGrad.com, 2009). Additionally, BLS estimates that almost half of all new jobs created between 2008 and 2018 will involve application of postsecondary education. Of the 50.9 million job openings BLS projects during that period 7.1 million will require a bachelors degree, 2.4 million an associates degree, 2.1 million a bachelors degree or higher plus work experience, 1 million a masters degree, .75 million a masters degree, and .74 million a doctoral degree (BLS, 2009b).

A report by the Conference Board, Society for Human Resource Management, Partnership for the $21^{\text {st }}$ Century, and Corporate Voices for Working Families provides a framework for applying those BLS projections. That study, "Are They Really Ready to Work," examined the nature of the contemporary U.S. workplace, and the readiness of its workers to contribute to it. The increasing competitive nature of the globalized business world was affirmed, and the resulting need for U.S. workers to move from an industrial to an information economy. The report 
concluded, "The future competitiveness of the U.S. business community will be dependent on America's ability to produce a highly skilled workforce" (The Conference Board, et. al., 2006b).

\section{PURPOSE AND METHOD}

The purpose of this paper is to contribute to the business and management literature, practice, and education by exploring the resulting timely topic: What skills should today's college graduates have to meet the challenges and access the opportunities of the workplace awaiting them? Identification and development of skills that ready the $21^{\text {st }}$ century workforce has been a priority for practitioners and educators for some time. For instance the premiere business school accrediting body, AACSB International, explicitly expects business schools to prepare students for $21^{\text {st }}$ century work. Employers, professional associations, researchers, and advisory boards support the wisdom of that expectation. Students and their parents seek education that delivers it. But there appears to be widespread uncertainty and variation of perceptions among administrators, faculty, career centers, and students as to what skills employers seek when recruiting and selecting recent college graduates for employment. Their subjective sources range from the anecdotal to the experiential, from the intuitive to the specialization.

Given the contextual factors described above, and the relatively uncharted path they present, the importance of informing perceptions with objective, comprehensive, and current information intensifies. So research for this paper reviewed data reported by established institutions including BLS, Collegiate Employment Research Institute (CERI) at Michigan State University (MSU), Economic Policy Institute, Gallup, NACE, Occupational Information Network (O’Net), Partnership for the $21^{\text {st }}$ Century, Society for Human Resource Management (SHRM), The Conference Board, U.S. Department of Education, U.S. Department of Labor; career web sites including Careerbuilder.com and CollegeGrad.com; and relevant academic and practitioner literature. More than 150 sources published within recent years were consulted. Literature from several years was intentionally considered since, given the unusual nature of the current economic environment, data from any single year might be non-reflective of longer lasting trends.

In addition, several original studies were also conducted for this paper to provide 360 degree perspective. Primary data available through O'Net was accessed to itemize skill sets associated with jobs requiring college degrees, primary data available through Collegegrad.com was collected to identify skill sets valued by those hiring the most entry level workers, primary data available through Careerbuilder.com was used to determine attributes human resource (HR) and hiring managers consider when hiring new college graduates, and a pilot study of employers of new college graduates in a range of industries was conducted to collect qualitative data providing a basis for comparison with conclusions from the existing reviewed literature. Throughout, the area of inquiry focused on gathering and reporting information of direct relevance to those seeking to prepare today's college students to be productive, fulfilled, and valued participants in the fast-changing, ever-more demanding contemporary workplace.

\section{LITERATURE REVIEW}

A review of the academic and practitioner literature to identify skills most important for college graduates to have finds several areas commonly identified, varied terminology used by different sources describing skills with some overlapping dimensions, and some skills identified as additionally salient by individual sources. Practitioners appear to be in wide agreement on the importance of today's college graduates possessing interpersonal, conceptual, and informational ability, coupled with drive and adaptability. An article in HR Magazine, for example, summarized the key workplace skills for new graduates to be communication, work ethic, teamwork, initiative, and leadership, and explained their value as helping a newly hired employee succeed and contribute to an organization (Owens, 2009). Concurrently Yahoo!hotjobs spotlighted essential skills for college graduates to be communication, technology, teamwork, leadership, independence, and flexibility (Essential Workplace Skills for College Grads, n. d.). The National Work Readiness Credential website reported business across industry sectors as citing the skills essential for entry level workers to be speaking so others can understand, listening actively, cooperating with others, observing critically, solving problems and making decisions, resolving conflicts and negotiating, taking responsibility for learning, reading with understanding, and using math to solve problems (Frequently Asked Questions, n. d.). MonsterTRAK identified the key workplace skills to be communication, self-motivation, teamwork, critical thinking, visionary qualities (brainstorm, look to the future, set goals), proficiency with 
information (inquire, research, be resourceful), and global mindedness (Tullier, n. d.).

At the start of this century, the CEO Forum specifically researched the key skills students should have. The CEO Forum reported the core " $21^{\text {st }}$ century skills" to be effective communication (teamwork/interpersonal/collaboration, personal/social responsibility, interactivity), digital age literacy (basic, scientific, and technical; cultural literacy and global awareness), inventive thinking (adaptability/managing complexity, curiosity/creativity/risk taking, higher order thinking/sound reasoning), and high productivity (prioritizing/planning/managing for results, using real-world tools effectively, creating relevant high-quality products) (CEO Forum, 2001).

Those preparing students for the contemporary workplace appear to identify core attributes paralleling those identified by practitioners as important. A study by AACSB identified the most popular business-related learning goals adopted by its accredited business schools. Learning goals reflect the competencies the schools believe most important for students to have developed through their higher education. The competencies AACSB International accredited schools collectively find most important, as reflected in the learning goals, are communication, ethics, knowledge of all business disciplines, critical thinking, decision-making, problem-solving, ability to integrate across business disciplines, global perspective, team skills, and competency in one's major (AACSB International, 2007).

Based on continual analysis of U.S. employment, the U.S. Department of Labor lists several categories of functional skills necessary for effective work performance. The core competencies its analysis has found are consistent with those identified above. The attributes the Department of Labor reports were identified in 1990 but remain posted as current. It notes these key abilities to be information management (acquire, use, and report), resource management (time, money, material, and people), social interaction (teamwork, instruct, influence, negotiate, serve customers), systems behavior and performance (anticipate/identify/manage consequences and monitor/correct performance), human and technology interaction, and affective skills (attitudes, motivation, and values) (Secretary's Commission on Achieving Necessary Skills, 1990).

Not only does there appear to be agreement about the importance of these core skill sets, but the concurrence of an academic meta-analysis suggests they may be of durable value. A 1999 literature review by Tanyel, Mitchell, and McAlum of skill set research conducted during the 1990s finds similar core skills identified. They report a 1993 study by Raymond et. al. of employer-identified attributes of entry level work success to be oral communication, writing, interpersonal, dependability, and self-start/motivation. They report a 1994 study by Paolillo finding most important skills for graduating business students to be communication, getting along with others, dependability, initiative, problem-solving, and creative thinking. They report a 1995-1996 study by Scheetz finding competencies best new college graduates have and/or skills necessary for new graduates to have as communication, teamwork, technology, willingness and ability to learn, organizational, leadership, analytical thinking/problemsolving, foreign language, and flexibility/adaptability. The original survey of prospective employers conducted by Tanyel et. al. for their paper found the most important attributes of newly hired business school graduates to be oral communication, ethical values, interpersonal, responsibility/accountability, time management/punctuality, teamwork, and decision making/analytical ability. Of these, employers said interpersonal ability, ethics, and responsibility/accountability are top attributes for a new graduate to possess (Tanyel, Mitchell, and McAlum, 1999).

A review of the literature finds some explaining and emphasizing an attribute pointed to but not as explicit in those commonly identified above: desirable attitude. Ingbretsen, for instance, states that having the right major, skill set, and interview facility are the baseline, after which one's affect plays a large role. He reports that capable people can learn new skills, but those with poor attitude can rarely be changed and efforts to attempt such change are likely to be costly as well as counterproductive. He describes employers in "good organizations" thus tending to "hire attitude, train skill" (Ingretsen, 2009). Tullier concurs. She, too, says that core ability to think, communicate, and interact with others are central to hiring decisions, after which technical skills will be trained. But she further states that positive outlook and confidence will affirmatively capture employer attention and interest in a person being considered (Tullier, n. d.). 
A report by the Gallup Organization emphasizes the role played by an additional attribute: political savvy. The study points out that many people who are intellectually smart do not get ahead or keep a job. Though they have innate potential and many of the typically cited requisite skills, they do not grasp the fundamentals of office politics - how decisions are made, teams are formed, and corporate culture works. Alternatively, many who get ahead are instead solid performers, able to assume more responsibility, and effective at comprehending and navigating themselves through the political realities of organizational dynamics (Saxena, 2006).

\section{COMPREHENSIVE SKILL STUDIES}

The shared interest in identifying critical attributes foundational to a skilled $21^{\text {st }}$ century U.S. workforce prompted several extensive studies that are instructive in gathering data from a spectrum of relevant respondent groups. A 2003 study by The Gallup Organization surveyed employed Americans and reported the importance they placed on 13 work-related skills. Seven of the attributes were selected as important by the majority of those aged 1829 , the cohort group most aligned with that of new college graduate employees: Interpersonal, critical thinking/conceptual, reading, computers, public speaking, math, and writing. These skills were also identified as the seven most important to the overall employment pool surveyed, though public speaking was found to be more important by the younger group of employees than to the overall employment pool (Lyons, 2003). Overall, possession of applied soft and basic cognitive skills appear to be perceived as more important than having more specialized/advanced capacities. Table 2 summarizes the findings of the Gallup study. Responses of less than 50\% are italicized.

Table 2: Workplace Skills Employees Cite as Important

\begin{tabular}{|l|c|c|}
\hline \multicolumn{1}{|c|}{ Attribute } & \% 18-29 & \% All \\
\hline Skill in dealing with people & 91 & 87 \\
\hline Critical thinking (creativity, decision making, and problem solving) & 81 & 84 \\
\hline Reading speed or comprehension & 69 & 61 \\
\hline Basic use of computers & 66 & 65 \\
\hline Public speaking & 60 & 49 \\
\hline Basic math & 57 & 56 \\
\hline Writing ability & 56 & 57 \\
\hline Advanced use of computers & 45 & 44 \\
\hline Physical strength & 45 & 33 \\
\hline Artistic skill & 33 & 23 \\
\hline Knowledge of history & 32 & 19 \\
\hline Advanced mathematics & 29 & 23 \\
\hline Knowledge of science or scientific principles & 25 & 27 \\
\hline
\end{tabular}

While the Gallup Organization queried employees, the 2006 "Are They Really Ready to Work" joint study by The Conference Board, Corporate Voices for Working Families, Partnership for $21^{\text {st }}$ Century Skills, and the SHRM surveyed and interviewed more than $400 \mathrm{HR}$ and other senior executives. The report was consistent with Gallup in finding that new workforce entrants need applied soft skills directly relevant to contemporary work, not just knowledge skills.

Respondents to the "Are They Really Ready to Work" study rated the importance of 20 workplace-related knowledge area and skills, and the proficiency in each possessed by workers with various levels of education. The majority of employers identified 15 of the skills to be very important. They reported that proficiency tends to increase as level of education advances, but that even new graduates with 4-year degrees tend to enter the workforce at most adequately skilled. Majorities did not report such graduates to be either excellent or deficient in any of the areas. More than $90 \%$ of respondents reported oral communication, teamwork/collaboration, professionalism/work ethic, written communication, and critical thinking/problem solving to be very important skills for 4-year graduates to possess. The majority of respondent also reported writing in English, English language, reading, social responsibility/ethics, leadership, information technology, creativity/innovation, lifelong learning/self-direction, diversity, and math to be skills very important for 4-year graduates to have (The Conference Board, 2006; The 
Conference Board, et. al, 2006a). Table 3 summarizes the report's findings. Responses of less than 50\% are italicized.

Table 3: Workplace Skills HR and Other Executives Cite as Very Important for 4-Year College Graduates

\begin{tabular}{|l|c|c|c|c|c|}
\hline \multicolumn{1}{|c|}{ Attribute } & $\begin{array}{c}\text { \% say vital for } \\
\text { 4-year grads }\end{array}$ & $\begin{array}{c}\text { \% say 4-year } \\
\text { grads excel }\end{array}$ & $\begin{array}{c}\text { \% say 4-year } \\
\text { grads adequate }\end{array}$ & $\begin{array}{c}\text { \% say 4-year } \\
\text { grads deficient }\end{array}$ & $\begin{array}{c}\text { \% say } \\
\text { importance will } \\
\text { grow; rank }\end{array}$ \\
\hline Oral communication & 95.4 & 24.8 & 75.2 & 0.0 & $65.9 ; 7$ \\
\hline Teamwork/collaborate & 94.4 & 24.6 & 76.4 & 0.0 & $74.2 ; 3$ \\
\hline Professionalism/work ethic & 93.8 & 0.0 & 100.0 & 0.0 & $64.4 ; 8$ \\
\hline Written communication & 93.1 & 0.0 & 52.2 & 27.8 & $64.0 ; 10$ \\
\hline Critical think/problem solve & 92.1 & 27.6 & 72.4 & 0.0 & $77.8 ; 1$ \\
\hline Writing in English & 89.7 & 0.0 & 73.8 & 26.2 & $45.4 ; 14$ \\
\hline English language & 88.0 & 26.2 & 73.8 & 0.0 & $32.8 ; 17$ \\
\hline Reading comprehension & 87.0 & 25.9 & 74.1 & 0.0 & $41.0 ; 15$ \\
\hline Ethics/social responsibility & 85.6 & 0.0 & 100.0 & 0.0 & $64.3 ; 9$ \\
\hline Leadership & 81.8 & 0.0 & 76.2 & 23.8 & $66.9 ; 6$ \\
\hline Information technology & 81.0 & 46.3 & 52.7 & 0.0 & $77.4 ; 2$ \\
\hline Creativity/innovation & 81.0 & 21.5 & 78.5 & 0.0 & $73.6 ; 4$ \\
\hline Lifelong learning/self direct & 78.3 & 25.9 & 74.1 & 0.0 & $64.0 ; 11$ \\
\hline Diversity & 71.8 & 28.3 & 71.7 & 0.0 & $67.1 ; 5$ \\
\hline Math & 64.2 & 0.0 & 100.0 & 0.0 & $48.8 ; 13$ \\
\hline Science & 33.4 & 14.6 & 85.4 & 0.0 & $38.7 ; 16$ \\
\hline Foreign languages & 21.0 & 6.2 & 93.8 & 0.0 & $63.3 ; 12$ \\
\hline Government/economics & 19.8 & 8.1 & 91.9 & 0.0 & $24.8 ; 18$ \\
\hline History/geography & 14.1 & 5.2 & 94.8 & 0.0 & $17.9 ; 19$ \\
\hline Humanities/arts & 13.2 & 9.2 & 90.8 & 0.0 & $9.5 ; 20$ \\
\hline
\end{tabular}

More than 990 employers were surveyed by CERI and MSU Career Services Network for their 2007-2008 "Recruiting Trends" report. Respondents were drawn from lists in Fortune, Inc., and those who recruit heavily on campus. Positive qualities expected in new college graduates hired, challenges/deficits employers see in new college graduates, and top reasons new college graduates are fired were reported (College Employment Research Institute, et. al., n. d.; and Hansen, 2009b). Responses regarding expected attributes are, again, consistent with those found by the other studies: Interpersonal, conceptual, informational, motivational/drive, and adaptability competencies are qualities identified as expected and identified as deficits when absent. Responses regarding deficits and reasons for termination are consistent with above-cited research that also point to the impact of attitudinal factors, whose specific itemization in this study contributes to better understanding of. Attributes in each category are ranked in Table 4 from most to least identified in the "Recruiting Trends" report.

Table 4: Workplace Attributes of New College Graduates Cited by Employers

\begin{tabular}{|l|l|}
\hline $\begin{array}{l}\text { Qualities employers } \\
\text { expect }\end{array}$ & $\begin{array}{l}\text { Energy, communication (verbal and written), technological aptitude, fresh perspectives/new ideas, } \\
\text { teamwork, willingness to learn, work ethic, analytical thinking, adaptability/embrace change }\end{array}$ \\
\hline Deficits employers find & $\begin{array}{l}\text { Entitlement attitude/unrealistic expectations, work ethic/laziness, lack of loyalty/commitment to } \\
\text { company, work-life balance, immaturity, lack of confidence, understanding work required, } \\
\text { communication skills, need for instant gratification }\end{array}$ \\
\hline $\begin{array}{l}\text { Top reasons they are } \\
\text { fired }\end{array}$ & $\begin{array}{l}\text { Unethical behavior, lack of motivation/work ethic, inappropriate use of technology, failure to } \\
\text { follow instructions, lateness to work, missing assignment deadlines }\end{array}$ \\
\hline
\end{tabular}

NACE also queries employers. It annually reports in a "Job Outlook" study of top characteristics some 275 employers seek in new college graduate hires. Respondents rank attributes on a scale of 1 low to 5 high. The same skills/qualities were ranked most important (averaged at least 4) in the 2007-2008 (Koncz and Collins, 2007) and 2008-2009 surveys. Characteristics many new college graduates lack were also reported in the 2008-2009 results (National Association of Colleges and Employers, n. d.). The attributes employers reported they were seeking are consistent with those cited above by others. Di Meglio emphasizes NACE's results as indicating that employers seek 
new college graduates with 'go-to-work' skills: Ability to work with other people, drive, and motivation (2008). The areas identified as important but not being highly present are consistent with those identified as only adequate by the "Are They Really Ready to Work?" study and attitudinal concerns noted earlier. Table 5 summarizes NACE's findings.

Table 5: Characteristics of New College Graduate Hires Cited by Employers

\begin{tabular}{|l|l|}
\hline $\begin{array}{l}\text { Characteristics of new graduates } \\
\text { most important to employers }\end{array}$ & $\begin{array}{l}\text { Communication (verbal and written), strong work ethic, teamwork (works well with } \\
\text { others), initiative, interpersonal (relates well to others), problem-solving, analytical, } \\
\text { flexibility/adaptability, computer, technical, detail-oriented, organizational }\end{array}$ \\
\hline $\begin{array}{l}\text { Characteristics many new } \\
\text { graduates lack }\end{array}$ & $\begin{array}{l}\text { Communication (presentation and written), teamwork, interpersonal, work ethic, time } \\
\text { management, multi-tasking to meet deadlines, realistic job expectations, job loyalty, } \\
\text { professionalism }\end{array}$ \\
\hline
\end{tabular}

In 2007, Partnership for $21^{\text {st }}$ Century Skills conducted a national poll of registered U.S. voters regarding contemporary skills today's students need to prepare them for the workplace. Respondents used a scale of 1 low to 10 high. Overall, the majority of respondents perceived most important skill sets similar to those identified by other studied groups identified above, though this study's respondents did perceive some of the skill sets (e.g. math, leadership, and creativity/innovation) highly valued by some others to be comparatively less important (2008). The percentage of respondents ranking each attribute as very important ( 9 or 10) in the 2007 survey is reported in Table 6. Responses of less than $50 \%$ are italicized.

Table 6: Skills Registered U.S. Voters Cite as Very Important for Today's Students

\begin{tabular}{|l|c|}
\hline \multicolumn{1}{|c|}{ Attribute } & \multicolumn{1}{c|}{ \% say very important } \\
\hline Reading comprehension & 75 \\
\hline Computer and technology & 71 \\
\hline Critical thinking and problem solving & 69 \\
\hline Ethics and social responsibility & 62 \\
\hline Written communication & 58 \\
\hline Teamwork and collaboration & 57 \\
\hline Oral communication & 56 \\
\hline Lifelong learning and self-direction & 50 \\
\hline Math & 48 \\
\hline Leadership & 44 \\
\hline Creativity and innovation & 43 \\
\hline Media literacy & 42 \\
\hline Global awareness & 42 \\
\hline Science & 38 \\
\hline
\end{tabular}

The five practitioner studies reported on above surveyed different respondent groups. Overall, five attributes were commonly identified as most important for today's students to possess. They are (alphabetically) communication - oral, communication - written, critical thinking/problem solving, information technology, and teamwork/collaboration. Five additional attributes were also indicated as important by a majority (3) of these studies. They are (alphabetically) creativity/innovation, leadership, lifelong learning/self-direction, professionalism/work ethic, and reading. Table 7 summarizes the presence or absence of various attributes reported as important in the five practitioner studies. "Y" (yes) indicates the attribute was reported by the study as important for today's students to have.

\section{PRACTITIONER WEB SITES}

Some 381 companies were identified as top entry level employers for 2009 by Collegegrad.com, selfdescribed as the \#1 entry level job web site for college students and recent graduates (Collegegrad.com, n.d.). Collegegrad.com provides access to each company's list of characteristics it values most in candidates for entry level jobs. Each employer rated the importance of eight criteria provided by Collegegrad.com on a scale of 1 high to 
8 low. Using that data, this paper was able to identify characteristics most valued by the 15 companies $^{3}$ projected to hire the most entry level workers; the companies ranged from Walgreens projecting 2000 such hires to Verizon Wireless projecting 13,198 such hires. Total scores per characteristic could range from a high of 15 (if ranked 1 by all companies), to a mid-range of 60 (if ranked 4 by all companies), to a low of 120 (if ranked 8 by all companies).

The Collegegrad.com data shows three attributes to be of clear above average value to top hirers of entry level workers. Interestingly, these top attributes are directly linked to college and academics: Major/degree, GPA, and college graduated from. The skills were given lesser importance, as was experience which is generally seen as a route to skill building. Overall importance of candidate characteristics identified by these employers are reported, ranked most to least important, in Table 8 . Individual rankings reported by each of the 15 companies are in Appendix A.

Table 7: Summary of Workplace Skills Practitioner Studies Found Most Important for Today's Students ${ }^{4}$

\begin{tabular}{|l|c|c|c|c|c|}
\hline \multicolumn{1}{|c|}{ Attribute } & Gallup & $\begin{array}{c}\text { The Conference } \\
\text { Board et.al. }\end{array}$ & CERI/MSU & NACE & $\begin{array}{c}\text { Partnership for } \\
\mathbf{2 1}^{\text {st }} \mathbf{C} \text {. Skills }\end{array}$ \\
\hline Communication- Oral & $\mathrm{Y}$ & $\mathrm{Y}$ & $\mathrm{Y}$ & $\mathrm{Y}$ & $\mathrm{Y}$ \\
\hline Communication - Written & $\mathrm{Y}$ & $\mathrm{Y}$ & $\mathrm{Y}$ & $\mathrm{Y}$ & $\mathrm{Y}$ \\
\hline Critical thinking/Problem solving & $\mathrm{Y}$ & $\mathrm{Y}$ & $\mathrm{Y}$ & $\mathrm{Y}$ & $\mathrm{Y}$ \\
\hline Information Technology & $\mathrm{Y}$ & $\mathrm{Y}$ & $\mathrm{Y}$ & $\mathrm{Y}$ & $\mathrm{Y}$ \\
\hline Teamwork/Collaboration & $\mathrm{Y}$ & $\mathrm{Y}$ & $\mathrm{Y}$ & $\mathrm{Y}$ & $\mathrm{Y}$ \\
\hline Creativity/Innovation & $\mathrm{Y}$ & $\mathrm{Y}$ & $\mathrm{Y}$ & & \\
\hline Leadership & $\mathrm{Y}$ & $\mathrm{Y}$ & & $\mathrm{Y}$ & \\
\hline Lifelong learning/Self-direction & & $\mathrm{Y}$ & $\mathrm{Y}$ & & $\mathrm{Y}$ \\
\hline Professionalism/Work ethic & & $\mathrm{Y}$ & $\mathrm{Y}$ & $\mathrm{Y}$ & \\
\hline Reading & $\mathrm{Y}$ & $\mathrm{Y}$ & & & $\mathrm{Y}$ \\
\hline Adaptability/Flexibility & & & $\mathrm{Y}$ & $\mathrm{Y}$ & \\
\hline Energy/drive/Initiative & & & $\mathrm{Y}$ & $\mathrm{Y}$ & \\
\hline Ethics/social Responsibility & & $\mathrm{Y}$ & & & $\mathrm{Y}$ \\
\hline Math & $\mathrm{Y}$ & $\mathrm{Y}$ & & & \\
\hline Diversity & $\mathrm{Y}$ & & & \\
\hline English Language & $\mathrm{Y}$ & & & \\
\hline Organizational/Detail-oriented & & $\mathrm{Y}$ & & & \\
\hline Writing In English & & & & & \\
\hline
\end{tabular}

Table 8: Valued Entry Level Candidate Characteristics Cited by Top Entry Level Employers

\begin{tabular}{|l|c|}
\hline \multicolumn{1}{|c|}{ Attribute } & Total scores from top 15 companies \\
\hline Major/degree & 38 \\
\hline GPA & 44 \\
\hline College graduated from & 44 \\
\hline Internship/experience & 57 \\
\hline Interviewing/communication skill & 71 \\
\hline Computer skills & 82 \\
\hline Personal appearance & 101 \\
\hline Other & 103 \\
\hline
\end{tabular}

\footnotetext{
${ }^{3}$ The top 15 entry level employers for 2009 identified by Collegegrad.com, the industry each employer self-described, and the number of new entry level hires projected by each are (Source: http://www.collegegrad.com/topemployers/2009_entry_level.php): 1 Verizon Wireless (Telecommunications) 13,198; 2 Enterprise Rent-A-Car (Automotive Rental, Leasing) 8K, 3 Internal Revenue Service (Financial Data Services) 5K, 4 Progressive Insurance (Insurance) 4,200, 5 DDP Holdings (Diversified Financials) 4K, 6 Teach for America (Education) 4K, 7 A $T / T$ (Telecommunications) 3428, 8 Deloitte \& Touche (Other) 3501, 9 Hertz (Automotive Rental, Leasing) 3K, 10 FBI (Security and Law Enforcement) 2950, 11 Ernst \& Young (Other) 2450, 12 KPMG (Other) 2400, 13 Boeing (Aerospace and Defense) 2200, 14 Lockheed Martin (Aerospace and Defense) 2025, 15 Walgreens (General Merchandise) 2000.

${ }^{4}$ The studies summarized varied in their terminology; some, for instance, surveyed broadly for interpersonal skill, while others specified teamwork and/or leadership. Table 7 reflects inferences derived from the overall responses to each study.
} 
Careerbuilder.com, self-described as the largest job-search/employment website, conducted its annual "College Job Forecast" survey between February 20, 2009 and March 11, 2009. Some 2500 hiring managers and HR professionals responded. The survey reported less than half (43\%) of employers planning to hire recent college graduates in 2009, a 13\% drop in that number from the year before. (Zupek, n. d.). Qualitative, open-ended responses from 25 companies identified as hiring new college graduates that year were reported. Using that data, 14 qualities these hirers of new college graduates apply were identified for this paper. The qualities cited by the openended responses paralleled those identified by other studies reported above.

The quality the highest number of companies in the Careerbuilder.com study reported applying was similar to that reported by those through Collegegrad.com, above: Education-linked. The majority of Careerbuilder.com's respondents also reported considering communication proficiency when hiring new college graduates, a finding consistent with other studies. Table 9 itemizes the 14 qualities and the cumulative extent to which each is mentioned as being used by the 25 companies, ranked most to least cited. Responses suggest that companies may vary in the attributes they prioritize in new college graduate hiring. Attributes reported as important by less than a majority of the respondents are italicized. Appendix B contains the qualities considered by each of the 25 companies when hiring new college graduates

Table 9: Attributes HR and Hiring Managers Cite as Considering When Hiring New College Graduates

\begin{tabular}{|l|c|}
\hline \multicolumn{1}{|c|}{ Attribute } & \# of companies applying the quality \\
\hline Educational-linked & 15 \\
\hline Communication (verbal and written) & 13 \\
\hline $\begin{array}{l}\text { Work ethic (includes responsibility, initiative, time management, discipline, } \\
\text { persistence, achieve results) }\end{array}$ & 11 \\
\hline $\begin{array}{l}\text { Drive (includes career focus, self-motivation, open to change, energy, } \\
\text { competitiveness) }\end{array}$ & 10 \\
\hline Interpersonal/teamwork & 10 \\
\hline Customer-focus/sales-minded & 7 \\
\hline Flexible/adaptable & 7 \\
\hline Computer & 6 \\
\hline Ethical & 6 \\
\hline Leadership & 6 \\
\hline Problem-solving/analytical/strategic thinker & 6 \\
\hline Entrepreneurial/ideas & 5 \\
\hline Work experience & 2 \\
\hline Other qualities & 12 \\
\hline
\end{tabular}

\section{QUALITATIVE PILOT STUDY RESULTS}

To more fully understand the extent to which and how employment techniques are used by contemporary employers, a pilot study of practitioners was also conducted for this paper. Seventeen such respondents in the fall of 2008 gave open-ended descriptions of the most important skills new college graduates should have to be productive entry level workers. They were also asked to describe the most important skills new college graduates should have if aspiring to management, the most important workplace skills most entry level new college graduates possess, and the most important workplace skills most entry level college graduates lack. Open-ended responses were intentionally solicited, to explore whether such responses would surface any valued attributes significantly different than those reported in the studies reported above, and to explore whether there are any differences in valued attributes for entry level workers who aspire to management positions. The timeframe in which the pilot study was conducted was prior to full awareness of the extent or duration of the Great Recession, and so may shelter the study's findings from distorted effects responses gathered in 2009 might have had

Ten of the pilot study's respondents identified their company's industry. The industries they represent are automobile (2), electronics, financial services, insurance, law, information technology, pharmaceutical, photography, and transportation. Table 10 contains the self-identified demographics of the 17 survey respondents. 
Table 10: Respondent Demographics

\begin{tabular}{|c|c|c|c|c|c|c|c|c|}
\hline Company Size & Large & $75 \%$ & Medium & $19 \%$ & Small & $6 \%$ & & \\
\hline Department & Corporate & $59 \%$ & $\mathrm{HR}$ & $18 \%$ & Line & $6 \%$ & Staff not HR & Other $12 \%$ \\
\hline Management Position & Senior & $41 \%$ & Middle & $35 \%$ & Lower & $6 \%$ & Non-management $18 \%$ & \\
\hline Age & $55+$ & $24 \%$ & $45-54$ & $41 \%$ & $33-44$ & $12 \%$ & $22-32$ & $22-$ \\
\hline Gender & Female & $53 \%$ & Male & $47 \%$ & & & & \\
\hline
\end{tabular}

Respondents' open-ended responses to this pilot study were categorized using the qualities applied to the open-ended responses reported in the Careerbuilder.com 2009 survey reported in Table 9 above. Both that study and this pilot study found majorities identifying communication ability as important to new college graduate hiring. Majorities of this pilot study also consider work ethic, interpersonal/team and computer skills to be most important, findings consistent with that of other reported research. Responses to this pilot study identified two additional valued attributes: Ability to manage, and business savvy/political/networking. Both were only mentioned as important to new college graduates aspiring to management posts. The latter, business savvy/political/networking, was discussed above as also reported by Gallup (Saxena, 2006) and was also cited by some respondents to this pilot study as a skill that is lacking. The majority of respondents reported one skill set to be possessed by most new college graduates: Computers. The majority of respondents reported one skill set to be both important for productive entry level workers and lacking in most new college graduates: Work ethic. Tables 11 and 12 present the responses to the pilot study.

Table 11: Skills of Entry Level College Graduates Cited by Pilot Study Practitioners as Most Important

\begin{tabular}{|c|c|c|c|c|}
\hline Attribute & $\begin{array}{c}\text { To be productive } \\
\text { entry level worker }\end{array}$ & $\begin{array}{c}\text { If aspire to } \\
\text { management job }\end{array}$ & Most possess & Most lack \\
\hline $\begin{array}{l}\text { Education-linked (includes technical and } \\
\text { academic knowledge)/GPA }\end{array}$ & 4 & 3 & 4 & 4 \\
\hline Communication & 13 & 14 & 7 & 6 \\
\hline Work ethic & 11 & 5 & 5 & 11 \\
\hline Drive & 4 & 5 & 4 & 1 \\
\hline Interpersonal/teamwork & 10 & 8 & 4 & 7 \\
\hline \multicolumn{5}{|l|}{ Customer/sales-minded } \\
\hline Flexible/adaptable & & 1 & & 2 \\
\hline Computer & 8 & & 11 & 1 \\
\hline Ethical & 2 & 3 & 1 & 4 \\
\hline Leadership & 1 & 7 & & 2 \\
\hline Problem-solving/analytic/strategic & 4 & 5 & 3 & 2 \\
\hline Entrepreneurial/ideas & & & & 1 \\
\hline Work experience & 1 & & & 1 \\
\hline Manage/delegate/decide & & 5 & & \\
\hline Business savvy/political/network & & 3 & & 4 \\
\hline
\end{tabular}

The pilot study's intent to solicit through open-ended responses valued attributes not routinely identified in other studies appears to have also surfaced top-of-mind practitioner concern with attitudinal dimensions of entry level college graduates, and to explain some of the characteristics of other attributes identified commonly in various studies as important to possess. Respondents expressed this most clearly in the words they used to describe specific qualities entry level college graduates should have but most do not. They described these absent qualities as lack of accepting direction, accountability, attention to detail, being on time, being thorough, dependability, diligence, dressing appropriately for business, ethical awareness, judgment and ethical decision making skills, knowing how to network and establish a mentor within the company, knowing how to work one's way up (need to earn trust and respect of colleagues and management), knowing one's place, making a connection on how one's work can impact the bottom line, thinking one owes the company who is paying one's salary rather than thinking one is owed by the company, patience, poise in speaking, resolve, staying on task, willingness to do grunt work part of every job, willingness to go above and beyond, and willingness to take on trivial tasks and see each as a learning experience. 
Respondents to the pilot study also identified some attributes that supplement those the Careerbuilder.com survey pinpointed, in each category this study explored. Table 12 reports these attributes. Along with those detailed above as most lacking, they help to specify facets of attitudinal dimensions valuable to possess that others reported above have suggested are important.

Table 12: Other Attributes of Entry Level College Graduates Cited by Pilot Study Practitioners as Most Important

\begin{tabular}{|l|l|l|l|l|}
\hline & To be productive entry level worker & If aspire to management & Most possess & \multicolumn{1}{c|}{ Most lack } \\
\hline $\begin{array}{l}\text { Other } \\
\text { qualities }\end{array}$ & $\begin{array}{l}\text { Enthusiasm, focus on organization not } \\
\text { self; personal grooming; apply learning }\end{array}$ & $\begin{array}{l}\text { Diplomacy, positive } \\
\text { influence }\end{array}$ & $\begin{array}{l}\text { Global; can } \\
\text { learn on the job }\end{array}$ & $\begin{array}{l}\text { Maturity; } \\
\text { grooming; know } \\
\text { one's place; apply } \\
\text { knowledge }\end{array}$ \\
\hline
\end{tabular}

\section{OCCUPATIONAL INFORMATION NETWORK (O’NET) RESULTS}

To fully understand the most important skills today's college graduates should have, the Occupational Information Network (O'Net) database was used to conduct an additional original study for this paper. The O'Net Resource website (http:/www.onetcenter.org) describes O'Net as developed under sponsorship of the U.S. Department of Labor Employment and Training Administration through a grant to the North Carolina Employment Security Commission. The database describes what U.S. jobs require and what those who do them know, are able to do, and are interested in ${ }^{5}$ based on information gotten through structured interviews of job holders and observations by industrial psychologists. Used by HR professionals and school counselors (Uhalde and Strohl with Simkins, 2006), O'Net identifies six workplace skill set groups: Basic (BAS), complex problem-solving (CPS), resource management (RM), social (SOC), systems (SYS), and technical (TECH). Each skill set group has component skills, as seen in Table 13. Together, the six workplace skills groups contain 35 skills $^{6}$. Appendix $\mathrm{C}$ specifies and groups each of the skills identified by O'Net (Occupational Information Network Resource Center, n. d.).

O’Net groups occupations/industries into 16 categories: Agriculture, food, and natural resources; architecture and construction; arts, video technology, and communication; business management and administration; education and training; finance; government and public administration; health science; hospitality and tourism; human services; information technology; law, safety, corrections, and security; marketing, sales, and service; manufacturing; science, engineering, technology, and maintenance; and transportation. Within these 16 occupations/industries, O'Net classifies 230 job types as requiring at least a college degree. Of those, O'Net classifies 121 jobs as being in high demand; the other 109 jobs requiring at least a college degree are not classified by O'Net as being in high demand.

To further explore the skills today's college graduates should have, the 35 skills in O'Net's six workplace skill set groups were mapped to the 230 jobs classified by O'Net as requiring at least a college degree. Skills associated with jobs classified as being in high demand for college graduates were recorded separately from skills associated with jobs not classified as being in high demand for college graduates. Table 13 reports the skills and

\footnotetext{
${ }^{5}$ Through on-the-job and organizational analysis, O’Net identifies six domains through which to specify key attributes and characteristics of workers and occupations. They are (Source: http://onetcenter.org):

- Worker characteristics: attributes that may influence work performance and ability to gain knowledge/skills required for effective work performance (e.g. abilities, occupational interests, work values, and work styles).

- Worker requirements: descriptors referring to work-related attributes gained through experience and education (e.g. basic skills, cross-functional skills, knowledge, and education).

- Experience requirements: requirements related to previous work activity linked to specific work activity (e.g. experience/training, basic skills/entry requirement, cross-functional skills/entry requirement, licensing).

- $\quad$ Occupation-specific information: elements of various occupations (e.g. tasks, and tools/technology).

- Workforce characteristics: variables describing characteristics of occupations that influence their requirements (e.g. labor market information, occupational outlook).

- Occupational requirements: variables describing what occupation requires (e.g. generalized work activities, detailed work activities, organizational context, and work context).

${ }^{6}$ Definitions of each of the 35 skills identified by O’Net can be found at http://online/onetcenter.org/skills/.
} 
skill set groups found from the O'Net data to be in the majority of jobs requiring at least a college degree overall, by jobs in high demand for college graduates, and by jobs not in high demand for college graduates.

As seen in Table 13, seven of the skills most associated with the high demand jobs and the non-high demand jobs are the same. Ranked in order of reported frequency in all jobs requiring a college degree, these most highly present skills are active listening, reading comprehension, critical thinking, speaking, active learning, writing, and time management. Five of these skills are consistent with those most commonly reported as important in the practitioner studies reported above. An interesting finding is that the skill most highly cited skill by O'Net, active listening, does not explicitly show up in those other studies. Time management is a second highly cited skill by O'Net that does not explicitly show up in those other studies; it was, however, identified as important in literature summarized above.

Table 13 also shows O'Net data finding that most high demand jobs involve two additional skills: Judgment and decision making, and complex problem solving. The majority of the non-high demand jobs uniquely involve instructing. Also of note is that four skills reported highly present are cited as more highly present in nonhigh demand jobs: Speaking, time management, active learning, and writing. Additionally, six of the most highly present skills are within the basic skill set group; none of the most highly present skills are found within the technical skill set group.

Appendix C further details the presence of each of O'Net's 35 skills in all jobs requiring at least a college degree, noting the level of market demand for the jobs. Among interesting findings in the data detailed there, given other reported demand for math and science competencies, is that only $21 \%$ of high demand jobs and $17 \%$ of nonhigh demand jobs presently involve math. Furthermore, only 17\% of high demand jobs and $28 \%$ of non-high demand presently involve science. Math and science are the two proficiencies in the basic skill set group presently associated with the fewest jobs requiring college degrees.

Table 13: Skills (and Skill Set Groups) Found in the Majority of Jobs Requiring at Least a College Degree

\begin{tabular}{|l|c|c|c|}
\hline Attribute & $\begin{array}{c}\text { \% in all 230 jobs } \\
\text { that require at least } \\
\text { a college degree }\end{array}$ & $\begin{array}{c}\text { \% in 121 high demand } \\
\text { jobs that require at least a } \\
\text { college degree }\end{array}$ & $\begin{array}{c}\text { \% in 109 other jobs that } \\
\text { require at least a college } \\
\text { degree }\end{array}$ \\
\hline Active listening (BAS) & 97 & 97 & 98 \\
\hline Reading comprehension (BAS) & 96 & 97 & 94 \\
\hline Critical thinking (BAS) & 93 & 93 & 94 \\
\hline Speaking (BAS) & 82 & 79 & 84 \\
\hline Time management (RM) & 79 & 65 & 75 \\
\hline Active learning (BAS) & 77 & 67 & 89 \\
\hline Writing (BAS) & 69 & 65 & 73 \\
\hline Judgment and decision making (SYS) & 55 & 69 & \\
\hline Complex problem solving (CPS) & & 52 & \\
\hline Instructing (SOC) & & & \\
\hline
\end{tabular}

When the skills O'Net data finds most highly present in jobs requiring college degrees are compared to valued attributes most commonly identified in the five practitioner studies reported on above, there is clear congruence on four competencies: Communication - oral, communication - written, critical thinking/problem solving, and reading. One other attribute prioritized in those practitioner studies also appears consistent with O'Net's findings, though the attribute is worded differently in various studies; where O'Net identifies active learning as highly present, the practitioner studies report the importance of lifelong learning/self-direction. Further, comparison of skills O'Net identified as present in today's jobs with characteristics practitioner studies investigated finds several attributes highly prioritized by practitioners not clearly linked to jobs requiring college degrees by O'Net: Creativity/innovation, leadership, professionalism/work ethic, and teamwork/collaboration. O'Net does find a social skill set group, in which leadership and teamwork/collaboration might be included. But of the attributes O'Net itemizes in that social skill set group, only instructing is reported to be somewhat highly present in jobs requiring college degrees. Moreover, the practitioner studies report information technology skill as highly important, while 
O'Net classifies information technology as an industry/occupation. O'Net does identify a technical skill set group but does not specify general information technology proficiency as a competence within that category. As reported above, O'Net data finds no technical skills among competencies most highly present in jobs requiring college degrees.

To then find whether skills identified as important by O'Net data are valued across industries/occupations, the number of occupations/industries in which the majority of jobs requiring college degrees use each skill was determined. Eight of the 35 skills identified by O'Net, found in three of the six skill set groups, were associated with most jobs requiring college degrees in the majority of the 16 occupations/industries in which O'Net has classified jobs. All of these eight skills are among the 10 skills itemized in Table 13 as found in most jobs requiring a college degree, and are reported in Table 14. Six of the eight skills found to be in most jobs requiring at least a college degree in the majority of occupations/industries are found in the basic skill set group. The two skills not found in the basic skill set group that are also highly present in jobs requiring at least a college degree in most occupations/industries are time management and judgment/decision making. No skills in the complex problem solving skill set group, social skill set group, or technical skill set group appear to be found in the majority of jobs requiring college degrees across occupations/industries.

Table 14: Skills (and Skill Set Groups) Found in Most Jobs Requiring at Least a College Degree in the Majority of Occupations/Industries

\begin{tabular}{|l|c|}
\hline \multicolumn{1}{|c|}{ Attribute } & \# of occupations/industries where majority of jobs use each skill \\
\hline Active listening (BAS) & 15 \\
\hline Critical thinking (BAS) & 15 \\
\hline Reading comprehension (BAS) & 15 \\
\hline Time management (RM) & 14 \\
\hline Speaking (BAS) & 13 \\
\hline Judgment and decision making (SYS) & 13 \\
\hline Active learning (BAS) & 11 \\
\hline Writing (BAS) & 11 \\
\hline
\end{tabular}

Appendix D details the presence of each of the 35 skills in the majority of jobs requiring college degrees in each of the 16 occupations/industries. Seven of these competencies are each found in most jobs requiring a college degree in only one occupation/industry: Learning strategies (education and training), math (agriculture, food, and natural resources), science (agriculture, food, and natural resources), management of personnel resources (architecture and construction), negotiation (marketing, sales, and service), systems analysis (information technology), and trouble shooting (information technology). Four additional skills (management of financial resources, management of material resources, persuasion, and systems evaluation) are not found in most jobs requiring a college degree in any occupation/industry.

\section{BEYOND SKILL SETS}

When seeking to help develop an able and employable workforce, it is instructive to note some additional factors beyond building designated skills that may impact the extent to which a new college graduate is seen as well qualified for work. First, of particular interest due to above cited research spotlighting education-linked criteria, the institution at which one's degree is earned may impact perception about the graduate's ability. A joint study by SHRM and WSJ.com/Careers found the majority of HR professionals surveyed agreeing that those who receive degrees from "highly reputable colleges and universities" are believed to be better prepared than those whose degrees are from "other colleges and universities" (2008). Salary data supports that value added perception. Data from Payscale.com finds those with undergraduate degrees from prestigious institutions, especially those in the Ivy League, earned the highest salaries even 10 years after graduating (Gopal, 2008).

Second, the degree/major earned may impact the likelihood that a new college graduate is on track with contemporary recruitment trends. Studies report that, unlike in earlier years when companies tended to recruit from a large variety of majors, employers are increasingly drawing from business and technical (engineering and computer 
science) graduates (Gardner, 2008; National Association of Colleges and Employers, n. d.). A CERI survey stated the proportion of 945 employers expecting to seek candidates with each major as business (40\%), engineering (36\%), computer science (18\%), science (15\%), liberal arts or humanities $(6 \%)$, and social science $(5 \%)$ (Hansen, 2009b). Jobweb.com ranked the majors in highest demand (listed top ranked of those in highest demand first) as accounting, mechanical engineering, electrical engineering, computer science, business administration/management, economics/finance, information sciences/systems, computer engineering, managing information systems, and marketing/marketing management (National Association of Colleges and Employers, n. d.). To the extent that salaries reflect perceived market worth, a NACE study of 200 college career centers is also of note. The 15 highest earning college degrees all involved math skills. In order, with the top ranked first, they are petroleum engineering, chemical engineering, mining engineering, computer engineering, computer science, electrical engineering, mechanical engineering, industrial engineering, systems engineering, engineering technician, actuarial science, aeronautics engineering, agricultural engineering, biomedical engineering, and construction management (Pepitone, 2009).

To the extent that one's major influences a graduate's marketability, the above figures suggest a factor that may be contributing to employer perception of graduates being insufficiently ready for work. Only $4 \%$ of U.S. college degrees tend to be awarded in engineering or computer science, while $15 \%$ of college degrees tend to be awarded in social science and 15\% in history (Pepitone, 2009). The degrees contemporary employers are least likely to seek in prospective hires appear to be among the more popular college majors. This may be furthering the perceived gap between competencies employers seek and those new college graduates have to offer (Hansen, 2009b).

\section{CREDENTIALING}

Reflecting the above, a national conversation appears to be occurring regarding U.S. workforce readiness, and how to optimize it. The 2006 "Are they Really Ready to Work" study conducted by four established workfocused organizations found the more than $400 \mathrm{HR}$ and other senior executives surveyed projecting that $85 \%$ of newly created US jobs through 2015 will require education beyond high school. The resulting concern is summarized in that study's conclusion: "The reports findings reflect employer's growing frustrations over the lack of skills they see in new workforce entrants" (The Conference Board, et. al., 2006a). SHRM's 2008 biennial "Workplace Forecast" report found the majority of respondents citing overall decline in workforce readiness of new entrants to labor markets in the U.S. compared with other countries, and poor educational performance of U.S. students compared with global competitors. Respondents ranked these factors as among key global trends most likely to have a major strategic impact on the workplace (Society for Human Resource Management, 2008).

Some are advocating that competence of new workforce entrants should be certified by credentials, separate from educational degrees, that when earned validate the prospective employee's relevant qualifications. Some states have moved to create such a nationally recognized "work readiness" credential, signifying one's ability to perform entry level work ${ }^{7}$, with performance attributes defined by employers. That credential would be earned by satisfactory performance on a 2-1/2 hour test assessing proficiency in reading comprehension, using math to solve problems, speaking and listening, and situational judgment. Reflecting concern about many new employees' work habits, situational and attitudinal aspects of the test would probe possession of soft skills like punctuality, openness to supervision, decision-making, conflict resolution and negotiation, responsibility for self-learning, and teamwork (Lazaroff, 2005; Frequently Asked Questions, n. d.). After three years of collaborative development between business, government, education, and workers, the National Work Readiness Council (NWRC) launched its National Work Readiness Credential (WRC). Founding jurisdictions were the District of Columbia, Florida, New Jersey, New York, and Rhode Island (McLester and McIntire, 2006).

Concurrently, some institutes of higher education are seeking ways to indicate their graduates' possession of workplace competencies not otherwise directly reflected in a traditional college transcript. Responding to continued recruiter requests for more information about graduates' soft skills the University of Wisconsin, for

\footnotetext{
${ }^{7}$ The National Work Readiness Council website defines entry work as a non-supervisory, non-managerial, non-professional post, skilled or unskilled, where skills can be learned on job (Source: hppt://www.workreadiness.com).
} 
instance, has considered creating a "dual transcript" that prospective employers and graduate school admissions committees could receive. One part of that transcript would provide traditional course grades. The other part would assess possession of relevant workplace skills like communication and leadership which might be seen through participation in extracurricular activity/jobs/internships and creative thinking displayed. That this might be well received by employers is signaled by Enterprise Rent-A-Car. One of the largest hirers of college graduates, Enterprise says it would welcome dual transcripts as it has long looked beyond candidate GPA and focused instead on candidate attributes. Enterprise says it wants to know, when hiring, that an applicant has been active in student organizations/athletics/community service, demonstrated leadership, communicated effectively, possessed a strong work ethic, thought on his/her feet, and been flexible (Di Meglio, 2008).

\section{LIMITATIONS AND IMPLICATIONS FOR FUTURE RESEARCH}

The uncertain nature of today's demanding times heightens the importance of identifying workplace competencies new college graduates should possess. The literature, extant studies of various practitioner groups, and primary data reported on above are relatively consistent in reporting that students should possess interpersonal, conceptual, and informational ability, coupled with drive and adaptability. These skills appear to be of durable value, as they appear to be commonly identified despite variance in type of study, respondent group, or moment in time. Ken Kay, President of the Partnership for $21^{\text {st }}$ Century Skills expressed the importance of these skills directly: "There isn't a lack of employees that are technically proficient but a lack of employees that can adequately communicate and collaborate, innovate and think critically" (Partnership for $21^{\text {st }}$ Century Skills, 2008).

Attitudinal factors ranging from professionalism and work ethic to time management, political savvy, and positive affect are also identified in the research reported on above as important. That they are described somewhat differently in various studies perhaps reflects the perceptual and subjective aspect of attitudinal attributes, which can make their impact all the more complex to positively possess and exhibit. The significance of these attitudinal factors, separate and in addition to the go-to-work skills summarized above, is pinpointed clearly by Hansen: "Hiring decisions clearly focus on skill sets, but firing decision shift to other (attitudinal) concerns" (2009b).

The need to optimally prepare today's college graduates with the above competencies is continually emphasized within the context of a contemporary workplace that is forecasting workforce deficits in critical competencies. That analytic framework was foundational to the "Are They Really Ready to Work" report, which described it this way: "U.S. companies are competing in an ever-increasing global marketplace where workers must transition from an industrial to a knowledge-based economy. But just as employers need decades of institutional knowledge to meet the challenges of the global business environment, the baby boom generation - the most experienced workers with the greatest knowledge and skills - are retiring" (The Conference Board, et. al., 2006b).

That marketplace transition may account for any disparity between studies in workplace competencies most important for today's college graduates to have. It may well be, for example, that O'Net data - extensive as it is in collection methodology - is more reflective of skills linked to present jobs, while studies based on responses of HR and hiring managers may be more reflective of future skill deficits prioritized to inoculate against projected absence of. Given this, the attributes identified above as commonly valued would appear to be all the more salient.

It is also constructive to identify any attributes that are strongly identified in some studies but overlooked in others. This may well be a result of differing studies surveying for unique factors. An outlier attribute that surfaces is the impact of education-linked factors: Major/knowledge, GPA, and college graduated from. This may be all the more intricate to address given that prestigious schools are likely to be most selective and thus fewer students can attend them, and that lower tuition at alternate schools may be an overriding attraction to many otherwise qualified students in tight economic times. Attending a college/university accredited by a highly respected accrediting body in one's field may well thus be a viable alternate strategy for a student; pursuing and receiving such accreditation may well be a parallel strategy for colleges and universities. Regardless, the constructive impact of educators being current on evolving workplace trends and the competencies valued there is a separate and seemingly desirable consideration, as is promoting educational climates that motivate and support high academic performance of students. 
There appears to be some disconnect in the data reported above, though, about the alignment between need for post- secondary education and workplace trends. Rampell reports that half of the college graduates under the age of 25 are in jobs not requiring a college degree (2009). Perhaps this is a momentary phenomenon reflecting the high unemployment of the Great Recession. The 2006 "Are they Really Ready to Work" report projected that 85\% of US jobs created through 2015 will require education beyond high school (The Conference Board, et. al., 2006a). But BLS' more recent 10-year projection of US job openings through 2018 reports only $27.68 \%$ requiring an associates degree or higher, and only $22.97 \%$ requiring a bachelors degree or higher (BLS, 2009b). This could mean that the Great Recession has negatively impacted need for postsecondary education in the near term, and/or that new jobs are more likely to require more education. Clarifying the number and nature of those jobs would seem to be important in applying the above findings most constructively. But doing so with reliability is complicated by the unusual nature of today's economy and resulting workplace impacts. Table 15 suggests resulting areas for future research.

Table 15: Areas for Future Research

What jobs/fields requiring college education are employers most likely to be seeking to fill through 2020 ?

How should colleges/universities best build skills and attitudes identified as important for their students to have?

Are instructors, credentialed in their teaching/research fields, qualified/interested in helping to build these attributes?

Are workplace skills/attitudes best built integrated with or separate from developing academic/technical knowledge?

How can colleges/universities motivate higher academic performance without heightening grade inflation?

\section{CONCLUSION}

Today's college graduates face an uncertain and demanding job market in which they are likely to encounter evolving skill needs, reduced hiring, and heightened competition from experienced laid off workers and globally available labor. It appears that higher education can be a route through which development of knowledge, skills, and attitude reflective of the contemporary workplace can help optimize that entry. Possession of these attributes may well replace what today's college graduates might have otherwise encountered as a grave new workplace world, with one that welcomes and utilizes them fully. Inbretsen expressed the resulting route to that reality this way:

"Employers are looking for candidates who have the right degree and skill-sets necessary for success in the position they are trying to fill. This may appear to be an obvious statement, but many college graduates don't take this basic message to heart. The completion of a degree does not guarantee a job. Employers want to know what you will do for them" (Ingbretsen, 2009).

\section{AUTHOR INFORMATION}

Susan Eisner is a Professor of Management at Ramapo College of NJ. Prior to teaching she held key positions in a leading television station, prominent foundation, national political party, and Presidential campaign. Her graduate degree is from Harvard University, where she was an Administration Fellow. Her research/teaching interests include organizational behavior/management, business and society, career building, generational and gender diversity, and pedagogy. She has received the Thomases Award for Faculty Excellence (All-College), and the Outstanding Teacher Award (Business School). Among listings recognizing her achievements are Who's Who in the World, Who's Who in America, and Who's Who Among America's Teachers.

\section{REFERENCES}

1. Ahrens, F. (2010, February 28). Economy watch: Three indicators spell trouble for the recovery. The Washington Post, p. G01.

2. Andrews, E. (2009, February 7). 598,000 jobs lost as jobless rate hit 7.6\% in January. The New York Times. Retrieved from http://www.nytimes.com.

3. Association to Advance Collegiate Schools of Business (AACSB) International. (2007, November 20). AACSB Assurance of learning standards: An interpretation. Retrieved from http://www.aacsb.edu/accreditation/papers. 
4. CEO Forum. (2001, June). The CEO forum school technology and readiness report - Key building blocks for student achievement in the $21^{\text {st }}$ century. Year 4 StaR Report. Retrieved from http:// www.ceoforum.org.

5. CollegeGrad.com. CollegeGrad.com names top entry-level employers for 2009: Entry-level job opportunities remain stable. (2009, April 21). Press Release. Retrieved from http://www.collegegrad.com/press/top-employer.shtml.

6. CollegeGrad.com. (n. d.). CollegeGrad.com top entry-level employers for 2009. Retrieved (2009, August 18)from http://www.collegegrad.com/press/topemployers/2009_entry_level.php.

7. Collegiate Employment Research Institute (CERI). (n. d.). Executive Summary: Recruiting trends 2008 2009. East Lansing MI: Michigan State University. Retrieved from http://www.ceri.msu.edu/.

8. Collegiate Employment Research Institute (CERI) and Michigan State University (MSU) Career Services Network with MonsterTRAK and Monster Intelligence. (n. d.). Recruiting trends 2007-2008. East Lansing MI: Michigan State University. Retrieved from http://www.ceri.msu.edu/.

9. Di Meglio, F. (2008, February 21). A transcript for soft skills. Business Week. Retrieved from http://www.businessweek.com.

10. Economic Policy Institute (EPI). (2009, September 7). Labor day by the numbers. EIP Fact Sheet. Washington D.C.: Economic Policy Institute. Retrieved from http://www.epi.org.

11. Essential workplace skills for college grads. (n. d.). Yahoo!hotjobs. Retrieved (2009, August 19) from http://hotjobs.yahool.com/jobseeker.

12. Frequently asked questions (FAQ's): Ready, willing, and capable. (n. d.). National Work Readiness Council Website (NWRC). Retrieved (2008, December 10) from http://workreadiness.com/faqs.html.

13. Gardner, P. (2008, November 20). Graduates will face fierce competition in the job front. College Employment Research Institute (CERI). East Lansing MI: Michigan State University. Retrieved from http://news.msu.edu.

14. Glover, L. (2009, July 20). Finding a job: Job search tips for a jobless recovery. Business Week. Retrieved from http://www.businessweek.com.

15. Goodman, P. (2009, September 27). U.S. job seekers exceed openings by record ratio. The New York Times. Retrieved from http://www.nytimes.com.

16. Gopal, P. (2008, August 7). Which college grads earn the most? Business Week. Retrieved from http://www.businessweek.com.

17. Hansen, F. (2009a, May). Enterprise's recruiting model transforms interns into managers. Workforce Management Online. Retrieved from http://www.workforce.com.

18. Hansen, F. (2009b, March). Recruiters still courting college grads, but signing fewer new hires. WorkforceManagement Online. Retrieved from http://www.workforce.com.

19. Ingbretsen, R. (2009, February 10). What employers really look for when hiring a college graduate in 2009. Enzine Articles. Retrieved from http://enzinearticles.com.

20. Kleinfield, N. (2009, October 11). Jobs wanted, any jobs at all. The New York Times. Retrieved from http://www.nytimes.com.

21. Koncz, A., and Collins, M. (2007, December 5). Perfect job candidate pairs communication skills with strong work ethic. NACE Web Press Release: News for Media Professionals. Bethlehem PA: National Association of Colleges and Employers (NACE). Retrieved from http://www.naceweb.org.

22. Lazaroff, L. Workforce needs polish, U.S. businesses declare; "Soft skills" such as punctuality lacking, employers, unions say. (2005, April 10). Chicago Tribune, p. 1.10.

23. Leonhardt, D. (2009, November 7). Broader measure of U.S. unemployment stands at $17.5 \%$. The New York Times. Retrieved from http://www.nytimes.com.

24. Lyons, L. (2003, August 26). Which skills hold the secret to success at work? Part II. The Gallup Organization. Retrieved from Gallup Brain database and http://www.gallup.com.

25. McLester, S., and McIntire, T. (2006, November 15). The workforce readiness crisis: We're not turning out employable graduates nor maintaining our position as a global competitor. Why? Technology \& Learning. Retrieved from http://www.techlearning.com.

26. National Association of Colleges and Employers (NACE). (n.d.). How you fit into the tight job market: Job outlook 2009. (n. d.). Jobweb. Retrieved (2009, August 19) from http://www.jobweb.org/studentarticles.

27. New York State Department of Labor (NYS DOL). (n. d.) National work readiness credential launch in September 2006. Retrieved (2008, December 10) from http://www.labor.state.ny.us/worforcepartners. 
28. Norris, F. (2009, October 4). The jobs news gets worse. The New York Times Week in Review. Retrieved from http://www.nytimes.com.

29. Occupational Information Network (O’Net) Resource Center. (n.d.). Retrieved (2008, December 18) at http://onetcenter.org/overview.html and http://online/onetcenter.org/skills/.

30. Owens, D. (2009, April). College recruiting in a downturn. HR Magazine. 54, 4, pp. 51-54.

31. Partnership for $21^{\text {st }}$ Century Skills. (2008, September 10). Report identifies inherent link between a $21^{\text {st }}$ century education system and economic success. Press Release. Retrieved from http://www.21centuryskills.org.

32. Pepitone, J. (2009, July 24). The most lucrative college degrees. CNNMoney.com. Retrieved from http://finance.yahoo.com/college-education/article.

33. Rampell, C. (2009, September 5). Teenage jobless rate reaches record high. The New York Times. Retrieved from http://www.nytimes.com.

34. Saxena, A. (2006, January 9). Mastering the art of office politics. The Gallup Organization. Retrieved from Gallup Brain database and http://www.gallup.com.

35. Schwartz, N. (2010, March 16). Tight credit seen as corporate debts come due. The New York Times, p. A1.

36. Secretary's Commission on Achieving Necessary Skills. (1990, September 14). Identifying and describing the skills necessary for work. Exhibit 1. Washington D.C.: U.S. Department of Labor. Retrieved (2008, August 28) from http://www.dol.gov.

37. Shin, A. (2009, January 4). College degree no shield as more jobs are slashed. The Washington Post. Retrieved from http://www.washingtonpost.com.

38. Society for Human Resource Management (SHRM). (2008, June). SHRM workplace forecast. Retrieved from http://www.shrm.org.

39. Society for Human Resource Management (SHRM) and Wall Street Journal (WSJ).com Careers. (2008, June). Critical skills needs and resources for the changing workforce. Retrieved from http://www.shrm.org./resources/surveys_published.

40. Tanyel, F., Mitchell, M., and McAlum, H. (1999, September/October). The skill set for new business school graduates: Do prospective employers and university faculty agree? Journal of Education for Business, 75, 1, pp. 33-37.

41. The Conference Board. (2006, October 2). Most young people entering the U.S. workforce lack critical skills essential for success. Retrieved from http://www.conferenence-board.org.

42. The Conference Board, Partnership for $21^{\text {st }}$ Century Skills, Corporate Voices for Working Families, and Society for Human Resource Management. (2006a, October 2). Are they really ready to work? Retrieved from http://www.21stcenturyskills.org.

43. The Conference Board, Partnership for $21^{\text {st }}$ Century Skills, Corporate Voices for Working Families, and Society for Human Resource Management. (2006b). Key findings: Are they really ready to work? Retrieved from http://www.21stcenturyskills.org.

44. Tullier, M. (n.d.). The skills you have and the skills they want. MonsterTRAK.com. Retrieved (2008, November 20) from http://www.monstertrak.com/career-guide/job-interview-tips/skills.

45. Uhalde, R., and Strohl, J., with Simkins, Z. (2006, December). America in the global economy - A background paper for the New Commission on the Skills of the American Workforce. Washington D.C.: National Center on Education and the Economy (NCEE).

46. U.S. Bureau of Labor Statistics (BLS). (2009a, April 1). Education levels and unemployment at the end of 2008. (2009, April 1). TED: The Editors Desk. Washington D.C.: U.S. Department of Labor. Retrieved from http://www.bls.gov.

47. U.S. Bureau of Labor Statistics (BLS). (2009b, November). Employment outlook: 2008-2018; Occupational employment projections to 2018. Monthly Labor Review. Washington D.C.: U.S. Department of Labor.Retrieved from http://www.bls.gov.

48. U.S. Bureau of Labor Statistics (BLS). (2010, January 8). Employment situation summary. Economics News Release. Washington D.C.: U.S. Department of Labor. Retrieved from http://www.BLS.gov.

49. U.S. Bureau of Labor Statistics (BLS). (2009c. October 2). The employment situation - September 2009. Employment Situation Summary. Washington D.C.: U.S. Department of Labor. Retrieved from http://www.data.bls.gov.

50. What college grads can expect out of the job market. (2009, February 26?). CNBC.com. Retrieved from http://www.cnbc.com.

51. Willis, B., and Schlissermann, C. (2010, January 9). Shrinking U.S. labor force keeps unemployment rate from rising. Business Week. Retrieved from http://www.businessweek.com.

52. Zupek, R. (n.d). 25 employers hiring the class of 2009. Careerbuilder.com. Retrieved (2009, August 19) from http://www.careerbuilder.com. 


\section{APPENDIX A.}

Candidate Characteristics Ranked 1 Low To 8 High By 15 Top Entry Level Employers

\begin{tabular}{|c|c|c|c|c|c|c|c|c|}
\hline Employer & $\begin{array}{l}\text { Major/ } \\
\text { Degree }\end{array}$ & GPA & $\begin{array}{c}\text { College } \\
\text { Degree } \\
\text { From }\end{array}$ & Interned & $\begin{array}{c}\text { Interviewing/ } \\
\text { Communication }\end{array}$ & $\begin{array}{l}\text { Computer } \\
\text { Skill }\end{array}$ & $\begin{array}{c}\text { Personal } \\
\text { Appearance }\end{array}$ & Other \\
\hline $\begin{array}{ll}\text { 1. } & \text { Verizon } \\
& \text { Wireless }\end{array}$ & 7 & 4 & 6 & 3 & 1 & 2 & 5 & 8 \\
\hline $\begin{array}{l}\text { 2. Enterprise } \\
\text { Rent-A- } \\
\text { Car }\end{array}$ & 5 & 7 & 8 & 1 & 2 & 6 & 4 & $\begin{array}{l}3 \\
\text { Lead- } \\
\text { ership }\end{array}$ \\
\hline 3. IRS & 2 & 3 & 1 & 4 & 6 & 5 & 7 & 8 \\
\hline $\begin{array}{ll}\text { 4. } & \begin{array}{l}\text { Progressive } \\
\text { Insurance }\end{array}\end{array}$ & 2 & 3 & 1 & 4 & 6 & 5 & 7 & 8 \\
\hline $\begin{array}{ll}\text { 5. } & \text { DDP } \\
& \text { Holdings }\end{array}$ & 2 & 3 & 1 & 4 & 6 & 5 & 7 & 8 \\
\hline $\begin{array}{l}\text { 6. Teach For } \\
\text { America }\end{array}$ & 5 & 2 & 6 & 4 & 3 & 7 & 8 & $\begin{array}{l}1 \\
\text { Lead- } \\
\text { ership }\end{array}$ \\
\hline 7. $\mathrm{AT} \& \mathrm{~T}$ & 2 & 1 & 3 & 5 & 4 & 6 & 7 & 8 \\
\hline 8. $\begin{array}{l}\text { Deloitte \& } \\
\text { Touche }\end{array}$ & 2 & 3 & 1 & 4 & 6 & 5 & 7 & 8 \\
\hline 9. Hertz & 2 & 3 & 1 & 4 & 6 & 5 & 7 & 8 \\
\hline 10. FBI & 2 & 3 & 1 & 4 & 6 & 5 & 7 & 8 \\
\hline $\begin{array}{ll}\text { 11. } & \begin{array}{l}\text { Ernst \& } \\
\text { Young }\end{array}\end{array}$ & 1 & 2 & 6 & 4 & 3 & 5 & 7 & 8 \\
\hline 12. KPMG & 1 & 2 & 3 & 5 & 4 & 7 & 6 & 8 \\
\hline 13. Boeing & 2 & 3 & 1 & 4 & 6 & 5 & 7 & 8 \\
\hline $\begin{array}{l}\text { 14. Lock-heed } \\
\text { Martin }\end{array}$ & 1 & 2 & 4 & 3 & 6 & 7 & 8 & $\begin{array}{l}5 \\
\text { Team } \\
\text { Work }\end{array}$ \\
\hline 15. Wal-greens & 2 & 3 & 1 & 4 & 6 & 5 & 7 & 8 \\
\hline
\end{tabular}

Data from CollegeGrad.com, n. d., retrieved 2009, August 18, from

http://www.collegegrad.com/press/topemployers/2009_entry_level.php). 


\section{APPENDIX B.}

Qualities* 25 Companies (Noting Industry Of Each) Hiring 2009 College Graduates Consider

\begin{tabular}{|c|c|c|c|c|c|c|c|c|c|c|c|c|c|}
\hline & 1 & 2 & 3 & 4 & 5 & 6 & 7 & 8 & 9 & 10 & 11 & 12 & 13 \\
\hline $\begin{array}{l}\text { Allstate } \\
\text { (Insurance) }\end{array}$ & Vary with position & $\mathrm{Y}$ & $\bar{Y}$ & & $\mathrm{Y}$ & & & $\mathrm{Y}$ & & & $\mathrm{Y}$ & & \\
\hline $\begin{array}{l}\text { Arcadis } \\
\text { (Engineering) }\end{array}$ & Knows field & $\mathrm{Y}$ & & & & & $\mathrm{Y}$ & & & $\begin{array}{c}\text { In } \\
\text { academic } \\
\text { activity }\end{array}$ & & & $\begin{array}{c}\text { Related } \\
\text { internship }\end{array}$ \\
\hline $\begin{array}{l}\text { Cbeyond } \\
\text { (Technology) } \\
\text { *14: Professional }\end{array}$ & & $\mathrm{Y}$ & $\mathrm{Y}$ & $\mathrm{Y}$ & $\mathrm{Y}$ & & & & & & & $\mathrm{Y}$ & \\
\hline $\begin{array}{l}\text { DISH Network } \\
\text { (TV Entertainment) }\end{array}$ & Intelligence & & $\mathrm{Y}$ & $\mathrm{Y}$ & & $\mathrm{Y}$ & & & & & & $\mathrm{Y}$ & \\
\hline $\begin{array}{l}\text { GEICO } \\
\text { (Insurance/ } \\
\text { Financial Services) }\end{array}$ & $\begin{array}{l}\text { Good grades; major in } \\
\text { business, liberal arts, } \\
\text { computer science, or } \\
\text { math }\end{array}$ & $\mathrm{Y}$ & & $\mathrm{Y}$ & & $\mathrm{Y}$ & & $\mathrm{Y}$ & & Potential & $\mathrm{Y}$ & & \\
\hline $\begin{array}{l}\text { GMAC } \\
\text { (Finance/Banking) } \\
\text { *14: Embrace } \\
\text { diversity }\end{array}$ & High performer & & $\mathrm{Y}$ & & & & $\mathrm{Y}$ & $\mathrm{Y}$ & $\mathrm{Y}$ & $\mathrm{Y}$ & $\mathrm{Y}$ & & \\
\hline $\begin{array}{l}\text { Harris (IT and } \\
\text { Communication) }\end{array}$ & $\begin{array}{l}\text { GPA } 2.8+: \\
\text { regionally accredited }\end{array}$ & $\mathrm{Y}$ & $\mathrm{Y}$ & & & & & & & & & & \\
\hline $\begin{array}{l}\text { Kaplan Higher Ed } \\
\text { (Education) }\end{array}$ & & & & $\mathrm{Y}$ & & & & & & & & & \\
\hline $\begin{array}{l}\text { The Kruger } \\
\text { Company } \\
\text { (Grocery/Retail) } \\
\text { *14: Well rounded }\end{array}$ & Excellence & $\mathrm{Y}$ & & $\mathrm{Y}$ & $\bar{Y}$ & $\mathrm{Y}$ & & & & & & & \\
\hline $\begin{array}{l}\text { Maxim Healthcare } \\
\text { Services } \\
\text { (Healthcare) }\end{array}$ & & & $\mathrm{Y}$ & $\mathrm{Y}$ & & $\mathrm{Y}$ & & & & & & & \\
\hline $\begin{array}{l}\text { Perot Systems } \\
\text { (IT) } \\
\text { *14: Has company } \\
\text { values/principles }\end{array}$ & & $\mathrm{Y}$ & $\mathrm{Y}$ & & $\bar{Y}$ & & & & $\mathrm{Y}$ & & $\mathrm{Y}$ & & $\begin{array}{c}\text { Health- } \\
\text { care or IT }\end{array}$ \\
\hline $\begin{array}{l}\text { Quest Diagnostics } \\
\text { (Healthcare) } \\
\text { *14: Desire/ability } \\
\text { to learn, work } \\
\text { independently }\end{array}$ & Strong background & & $\mathrm{Y}$ & & & & $\mathrm{Y}$ & & & & & & \\
\hline $\begin{array}{l}\text { Rite Aid } \\
\text { Corporation } \\
\text { (Retail Pharmacy) }\end{array}$ & All majors & $\mathrm{Y}$ & $\mathrm{Y}$ & & & $\mathrm{Y}$ & & & $\mathrm{Y}$ & $\mathrm{Y}$ & & $\mathrm{Y}$ & \\
\hline $\begin{array}{l}\text { Robert Bosch } \\
\text { (Technology and } \\
\text { Services) } \\
* 14: \text { Geographically } \\
\text { mobile }\end{array}$ & $\begin{array}{l}\text { GPA 3-3.2+; } \\
\text { electrical/mechanical } \\
\text { engineering, finance, } \\
\text { accounting, HR, } \\
\text { sales/marketing, or } \\
\text { supply chain majors }\end{array}$ & $\mathrm{Y}$ & & & & & & & & & & & $\begin{array}{l}\text { Up to } 3 \\
\text { years } \\
\text { full-time }\end{array}$ \\
\hline $\begin{array}{l}\text { Ryder Systems } \\
\text { (Transportation) }\end{array}$ & & $\mathrm{Y}$ & $\mathrm{Y}$ & $\mathrm{Y}$ & $\mathrm{Y}$ & & $\mathrm{Y}$ & $\mathrm{Y}$ & & & $\mathrm{Y}$ & & \\
\hline $\begin{array}{l}\text { Sabre Holdings } \\
\text { (IT) }\end{array}$ & & & $\mathrm{Y}$ & & $\mathrm{Y}$ & & & & & & & $\mathrm{Y}$ & $\mathrm{Y}$ \\
\hline
\end{tabular}


Appendix B. continued

\begin{tabular}{|c|c|c|c|c|c|c|c|c|c|c|c|c|c|}
\hline & 1 & 2 & 3 & 4 & 5 & 6 & 7 & 8 & 9 & 10 & 11 & 12 & 13 \\
\hline $\begin{array}{l}\text { Sara Lee (Food/ } \\
\text { Beverage) }\end{array}$ & & & & $\mathrm{Y}$ & & & & & & & & & \\
\hline $\begin{array}{l}\text { Shell Oil Company } \\
\text { (Oil/Gas) } \\
\text { *14: Achievements }\end{array}$ & $3.2+$ & & & & $\bar{Y}$ & & & $\mathrm{Y}$ & & & $\mathrm{Y}$ & $\mathrm{Y}$ & \\
\hline $\begin{array}{l}\text { The Sherwin- } \\
\text { Williams Company } \\
\text { (Other) } \\
\text { *14: Willing to } \\
\text { relocate to advance }\end{array}$ & Bachelors Degree & & & & & & & & $\mathrm{Y}$ & $\mathrm{Y}$ & & & $\begin{array}{l}\text { Customer } \\
\text { service } \\
\text { or sales }\end{array}$ \\
\hline $\begin{array}{l}\text { Sodexo } \\
\text { (Hospitality/ } \\
\text { Contract) } \\
* 14: \text { Knowledge of } \\
\text { finance/business }\end{array}$ & & $\mathrm{Y}$ & & $\mathrm{Y}$ & & & $\mathrm{Y}$ & & $\mathrm{Y}$ & & & & \\
\hline $\begin{array}{l}\text { Sun Microsystems } \\
\text { (Network } \\
\text { Infrastructure) } \\
* 14: \text { Balance } \\
\text { academics, } \\
\text { internship, and } \\
\text { extracurricular }\end{array}$ & $\begin{array}{l}\text { Computer science and } \\
\text { electrical engineering }\end{array}$ & & & & & & & & & & & & \\
\hline $\begin{array}{l}\text { Tyson Foods Inc. } \\
\text { (Food Services) } \\
\text { *14: Diverse, } \\
\text { transferable skills }\end{array}$ & $\begin{array}{l}\text { Animal science, food } \\
\text { science, business, or } \\
\text { IT majors }\end{array}$ & & & & & & & & & & & & \\
\hline $\begin{array}{l}\text { United Health } \\
\text { Group (Heathcare) }\end{array}$ & Smart & & $\mathrm{Y}$ & $\mathrm{Y}$ & $\mathrm{Y}$ & & $\mathrm{Y}$ & & & & & & \\
\hline $\begin{array}{l}\text { Weichert Realtors } \\
\text { (Rear Estate) }\end{array}$ & & $\mathrm{Y}$ & & & $\mathrm{Y}$ & $\mathrm{Y}$ & & $\mathrm{Y}$ & & & & & \\
\hline $\begin{array}{l}\text { Whirlpool } \\
\text { Corporation } \\
\text { (Manufacturing, } \\
\text { durable goods, } \\
\text { consumer } \\
\text { products) } \\
\text { *14: Results record }\end{array}$ & & $\mathrm{Y}$ & & & $\mathrm{Y}$ & $\mathrm{Y}$ & $\mathrm{Y}$ & & $\mathrm{Y}$ & $\mathrm{Y}$ & & & \\
\hline
\end{tabular}

Data from Zupek, n.d., retrieved 2009, August 19, from http://www.careerbuilder.com.

\section{* Appendix B Legend: Qualities}

1. Educational-linked

2. Communication (verbal and written)

3. Work ethic (includes responsibility, initiative, time management, discipline, persistence, achieve results)

4. Drive (includes career focus, self-motivation, open to change, energy, competitiveness)

5. Interpersonal/teamwork

6. Customer-focus/sales-minded

7. $\quad$ Flexible/adaptable

8. Computer

9. Ethical

10. Leadership

11. Problem-solving/analytical/strategic thinker

12. Entrepreneurial/ideas

13. Work experience

14. Other qualities (if reported, listed under the company's name*) 


\section{APPENDIX C.}

Presence Of O'net's 35 Skills In 230 Jobs Requiring College Degrees, Noting Market Demand**

\begin{tabular}{|c|c|c|c|c|c|c|}
\hline Skill Set Group/Skill & \# in HD & \# in NHD & $\%$ in $\mathrm{HD}$ & $\%$ in NHD & $\#$ in $\mathbf{A L L}$ & $\%$ in $\mathbf{A L L}$ \\
\hline \multicolumn{7}{|l|}{ Basic Skills Group (10 Skills) } \\
\hline Active Learning & 81 & 97 & 67 & 89 & 178 & 77 \\
\hline Active Listening & 117 & 107 & 97 & 98 & 224 & 97 \\
\hline Critical Thinking & 112 & 102 & 93 & 94 & 214 & 93 \\
\hline Learning Strategies & 25 & 46 & 21 & 42 & 71 & 31 \\
\hline Mathematics & 26 & 19 & 21 & 17 & 45 & 20 \\
\hline Monitoring & 50 & 43 & 41 & 39 & 93 & 40 \\
\hline Reading Comprehension & 117 & 103 & 97 & 94 & 220 & 96 \\
\hline Science & 20 & 30 & 17 & 28 & 50 & 22 \\
\hline Speaking & 96 & 92 & 79 & 84 & 188 & 82 \\
\hline Writing & 79 & 80 & 65 & 73 & 159 & 69 \\
\hline \multicolumn{7}{|l|}{$\begin{array}{l}\text { Complex Problem Solving Skills } \\
\text { Group (1 Skill) }\end{array}$} \\
\hline Complex Problem Solving & 63 & 37 & 52 & 34 & 100 & 43 \\
\hline $\begin{array}{l}\text { Resource Management } \\
\text { Skills Group (4 Skills) }\end{array}$ & 0 & 0 & 0 & 0 & & \\
\hline Management of Financial Resources & 7 & 4 & 6 & 4 & 11 & 5 \\
\hline Management of Material Resources & 1 & 1 & 1 & 1 & 2 & 1 \\
\hline Management of Personnel Resources & 14 & 10 & 12 & 9 & 24 & 10 \\
\hline Time Management & 79 & 82 & 65 & 75 & 161 & 70 \\
\hline \multicolumn{7}{|l|}{ Social Skills Group (6 Skills) } \\
\hline Coordination & 42 & 35 & 35 & 32 & 77 & 33 \\
\hline Instructing & 32 & 61 & 26 & 56 & 93 & 40 \\
\hline Negotiation & 13 & 6 & 11 & 6 & 19 & 8 \\
\hline Persuasion & 11 & 7 & 9 & 6 & 18 & 8 \\
\hline Service Orientation & 30 & 8 & 25 & 7 & 38 & 17 \\
\hline Social Perceptiveness & 45 & 43 & 37 & 39 & 88 & 38 \\
\hline \multicolumn{7}{|l|}{ Systems Skills Group (3 Skills) } \\
\hline Judgment and Decision Making & 83 & 44 & 69 & 40 & 127 & 55 \\
\hline Systems Analysis & 10 & 4 & 8 & 4 & 14 & 6 \\
\hline Systems Evaluation & 5 & 1 & 4 & 1 & 6 & 3 \\
\hline Skill Set Group/Skill & $\#$ in HD & $\#$ in NHD & $\%$ in HD & $\%$ in NHD & \# in ALL & $\%$ in ALL \\
\hline \multicolumn{7}{|l|}{ Technical Skills Group (11 Skills) } \\
\hline Equipment Maintenance & 1 & 0 & 1 & 0 & 1 & 0 \\
\hline Equipment Selection & 5 & 9 & 4 & 8 & 14 & 6 \\
\hline Installation & 1 & 0 & 1 & 0 & 1 & 0 \\
\hline Operation and Control & 4 & 0 & 3 & 0 & 4 & 2 \\
\hline Operation Monitoring & 4 & 0 & 3 & 0 & 4 & 2 \\
\hline Operations Analysis & 10 & 5 & 8 & 5 & 15 & 7 \\
\hline Programming & 3 & 1 & 2 & 1 & 4 & 2 \\
\hline Quality Control Analysis & 7 & 3 & 6 & 3 & 10 & 4 \\
\hline Repairing & 1 & 0 & 1 & 0 & 1 & 0 \\
\hline Technology Design & 5 & 5 & 4 & 5 & 10 & 4 \\
\hline Trouble Shooting & 11 & 5 & 9 & 5 & 16 & 7 \\
\hline
\end{tabular}

Data from Occupational Information Network (O’Net), n.d., retrieved 2008, December 18, at http://online/onetcenter.org/skills/).

** 121 of the jobs are reported by O'Net as being in high demand (HD); the other 109 are not classified by O'Net as being in high demand (NHD) 


\section{APPENDIX D.}

Presence Of O'net's 35 Skills In 230 Jobs Requiring College Degrees By Occupation/Industry***

\begin{tabular}{|c|c|c|c|c|c|c|c|c|c|c|c|c|c|c|c|c|}
\hline $\begin{array}{l}\text { Occupation/ } \\
\text { Industry Legend \# }\end{array}$ & 1 & 2 & 3 & 4 & 5 & 6 & 7 & 8 & 9 & 10 & 11 & 12 & 13 & 14 & 15 & 16 \\
\hline $\begin{array}{l}\text { \# Of Its Jobs Requiring } \\
\text { College Degrees }\end{array}$ & 20 & 6 & 14 & 24 & 54 & 7 & 9 & 32 & 4 & 12 & 10 & 9 & 5 & 0 & 17 & 7 \\
\hline Skill And \# Of Occupations & $\%$ & $\%$ & $\%$ & $\%$ & $\%$ & $\%$ & $\%$ & $\%$ & $\%$ & $\%$ & $\%$ & $\%$ & $\%$ & $\%$ & $\%$ & $\%$ \\
\hline /Industries Where Majority Of & in & in & in & in & in & in & in & in & in & in & in & in & in & in & in & in \\
\hline Jobs Use Skill & 1 & 2 & 3 & 4 & 5 & 6 & 7 & 8 & 9 & 10 & 11 & 12 & 13 & 14 & 15 & 16 \\
\hline \multicolumn{17}{|l|}{ Basic Skills } \\
\hline Active Learning (11) & 95 & 33 & 79 & 42 & 89 & $\mathrm{~A}$ & 78 & 84 & 25 & 67 & 70 & $\mathrm{~A}$ & 80 & 0 & 88 & 43 \\
\hline Active Listening (15) & $\mathrm{A}$ & $\mathrm{A}$ & $\mathrm{A}$ & $\mathrm{A}$ & 98 & $\mathrm{~A}$ & $\mathrm{~A}$ & $\mathrm{~A}$ & $\mathrm{~A}$ & $\mathrm{~A}$ & 80 & $\mathrm{~A}$ & $\mathrm{~A}$ & 0 & 88 & 86 \\
\hline Critical Thinking (15) & 90 & $\mathrm{~A}$ & 93 & 88 & 89 & $\mathrm{~A}$ & 89 & $\mathrm{~A}$ & $\mathrm{~A}$ & 83 & $\mathrm{~A}$ & $\mathrm{~A}$ & $\mathrm{~A}$ & 0 & 94 & $\mathrm{~A}$ \\
\hline Learning Strategies (1) & 10 & 0 & 21 & 8 & 89 & 14 & 22 & 19 & 0 & 17 & 10 & 11 & 0 & 0 & 18 & 0 \\
\hline Mathematics (1) & 50 & 33 & 7 & 29 & 11 & 43 & 22 & 6 & 0 & 8 & 10 & 0 & 20 & 0 & 47 & 14 \\
\hline Monitoring (4) & 35 & 33 & 64 & 42 & 52 & 43 & 11 & 41 & 50 & 58 & 40 & 11 & 20 & 0 & 18 & 29 \\
\hline Reading Comprehension (15) & 95 & $\mathrm{~A}$ & 86 & $\mathrm{~A}$ & 98 & $\mathrm{~A}$ & 89 & $\mathrm{~A}$ & 75 & 92 & $\mathrm{~A}$ & 89 & $\mathrm{~A}$ & 0 & $\mathrm{~A}$ & 71 \\
\hline Science (1) & 65 & 0 & 0 & 0 & 20 & 0 & 11 & 47 & 0 & 17 & 0 & 11 & 0 & 0 & 41 & 0 \\
\hline Speaking (13) & 75 & 83 & 93 & 79 & $\mathrm{~A}$ & 71 & 78 & 81 & $\mathrm{~A}$ & $\mathrm{~A}$ & 30 & 89 & 60 & 0 & 59 & 57 \\
\hline Writing (11) & 75 & $\mathrm{~A}$ & 64 & 75 & 83 & 29 & $\mathrm{~A}$ & 47 & 50 & 58 & 30 & 89 & 80 & 0 & 76 & 43 \\
\hline \multicolumn{17}{|l|}{$\begin{array}{l}\text { Complex Problem Solving } \\
\text { Skills }\end{array}$} \\
\hline Complex Problem Solving (8) & 45 & 83 & 7 & 29 & 15 & 29 & 78 & 72 & 50 & 17 & 80 & 56 & 20 & 0 & 88 & 71 \\
\hline \multicolumn{17}{|l|}{$\begin{array}{l}\text { Resource Management } \\
\text { Skills }\end{array}$} \\
\hline Management of Financials (0) & 20 & 0 & 0 & 17 & 0 & 43 & 0 & 0 & 0 & 0 & 0 & 0 & 0 & 0 & 0 & 0 \\
\hline Management of Materials (0) & 5 & 0 & 0 & 4 & 0 & 0 & 0 & 0 & 0 & 0 & 0 & 0 & 0 & 0 & 0 & 0 \\
\hline Management of Personnel (1) & 10 & 50 & 29 & 21 & 6 & 0 & 0 & 0 & 25 & 17 & 10 & 0 & 20 & 0 & 6 & 14 \\
\hline Time Management (14) & 80 & 83 & $\mathrm{~A}$ & 67 & 72 & 86 & 56 & 50 & $\mathrm{~A}$ & 75 & 40 & 78 & 80 & 0 & 65 & 71 \\
\hline & & & & & & & & & & & & & & & & \\
\hline \multicolumn{17}{|l|}{ Social Skills } \\
\hline Coordination (4) & 40 & 83 & 71 & 67 & 11 & 29 & 22 & 28 & 75 & 42 & 30 & 22 & 20 & 0 & 18 & 29 \\
\hline Instructing (2) & 20 & 0 & 21 & 21 & 93 & 14 & 44 & 41 & 25 & 50 & 0 & 33 & 20 & 0 & 6 & 14 \\
\hline Negotiation (1) & 5 & 0 & 7 & 21 & 4 & 0 & 11 & 0 & 0 & 8 & 0 & 22 & 60 & 0 & 6 & 29 \\
\hline Persuasion $(0)$ & 5 & 17 & 7 & 21 & 2 & 14 & 11 & 0 & 0 & 8 & 0 & 33 & 40 & 0 & 0 & 14 \\
\hline Service Orientation (2) & 0 & 0 & 0 & 29 & 6 & 43 & 33 & 28 & 50 & 67 & 10 & 0 & 20 & 0 & 0 & 14 \\
\hline Social Perceptiveness (5) & 15 & 0 & 50 & 29 & 48 & 43 & 44 & 44 & $\mathrm{~A}$ & 75 & 10 & 56 & 60 & 0 & 6 & 14 \\
\hline \multicolumn{17}{|l|}{ Systems Skills } \\
\hline $\begin{array}{l}\text { Judgment/Decision Making } \\
\text { (13) }\end{array}$ & 55 & 83 & 79 & 79 & 7 & A & 89 & 69 & 75 & 42 & 60 & 78 & 80 & 0 & 59 & 71 \\
\hline Systems Analysis (1) & 5 & 0 & 0 & 13 & 0 & 0 & 0 & 3 & 0 & 0 & 60 & 0 & 0 & 0 & 18 & 0 \\
\hline Systems Evaluation (0) & 0 & 0 & 0 & 4 & 0 & 0 & 0 & 0 & 0 & 0 & 30 & 0 & 0 & 0 & 12 & 0 \\
\hline \multicolumn{17}{|l|}{ Technical Skills } \\
\hline Equipment Maintenance (0) & 0 & 0 & 0 & 0 & 0 & 0 & 0 & 0 & 0 & 0 & 0 & 0 & 0 & 0 & 0 & 14 \\
\hline Equipment Selection (0) & 0 & 0 & 0 & 0 & 2 & 0 & 0 & 22 & 0 & 0 & 0 & 11 & 0 & 0 & 18 & 29 \\
\hline Installation $(0)$ & 0 & 0 & 0 & 0 & 0 & 0 & 0 & 0 & 0 & 0 & 0 & 0 & 0 & 0 & 0 & 14 \\
\hline Operation and Control (0) & 0 & 0 & 0 & 4 & 0 & 0 & 0 & 3 & 0 & 0 & 0 & 0 & 0 & 0 & 0 & 29 \\
\hline Operation Monitoring (0) & 0 & 0 & 0 & 0 & 0 & 0 & 0 & 6 & 0 & 0 & 0 & 0 & 0 & 0 & 0 & 29 \\
\hline Operations Analysis (0) & 0 & 17 & 14 & 8 & 4 & 0 & 0 & 0 & 0 & 0 & 30 & 0 & 20 & 0 & 18 & 14 \\
\hline Programming (0) & 0 & 0 & 0 & 0 & 0 & 0 & 0 & 0 & 0 & 0 & 40 & 0 & 0 & 0 & 0 & 0 \\
\hline Quality Control Analysis (0) & 5 & 0 & 0 & 4 & 0 & 0 & 11 & 3 & 0 & 0 & 20 & 11 & 0 & 0 & 12 & 14 \\
\hline Repairing (0) & 0 & 0 & 0 & 0 & 0 & 0 & 0 & 0 & 0 & 0 & 0 & 0 & 0 & 0 & 0 & 14 \\
\hline Technology Design (0) & 0 & 0 & 0 & 0 & 0 & 0 & 0 & 6 & 0 & 0 & 40 & 0 & 0 & 0 & 18 & 14 \\
\hline Trouble Shooting (1) & 0 & 0 & 7 & 0 & 2 & 0 & 0 & 0 & 0 & 0 & 70 & 0 & 0 & 0 & 24 & 43 \\
\hline
\end{tabular}


Data from Occupational Information Network (O’Net), n. d., retrieved 2008, December 18, at http://online/onetcenter.org/skills/).

In Table D the Legend \# identifies the occupation/industry, \% reports the percentage of jobs requiring college degrees in each occupation/industry that use the skill, and " $\mathrm{A}$ " indicates $100 \%$ (all).

*** Appendix D Legend: Occupation/Industry

1. Agriculture, food, and natural resources

2. Architecture and construction

3. Arts, video technology, and communication

4. Business management and administration

5. Education and training

6. Finance

7. Government and public administration

8. Health science

9. Hospitality and tourism

10. Human services

11. Information technology

12. Law, safety, corrections, and security

13. Marketing, sales, and service

14. Manufacturing

15. Science, engineering, technology, and maintenance

16. Transportation 